Article

\title{
Social Responsibility toward the Employees and Career Development Sustainability during Manufacturing Transformation in China
}

\author{
Xuemei Lu ${ }^{1}$, Wenzhong Zhu ${ }^{2, *}$ and Fu-Sheng Tsai ${ }^{3,4,5, *}$ \\ 1 School of English for International Business, Guangdong University of Foreign Studies, \\ Guangzhou 510420, China \\ 2 School of Business, Guangdong University of Foreign Studies, Guangzhou 510006, China \\ 3 Department of Business Administration, Cheng Shiu University, Kaohsiung 83347, Taiwan \\ 4 Center for Environmental Toxin and Emerging-Contaminant Research, Cheng Shiu University, \\ Kaohsiung 83347, Taiwan \\ 5 Super Micro Mass Research and Technology Center, Cheng Shiu University, Kaohsiung 83347, Taiwan \\ * Correspondence: 200211106@oamail.gdufs.edu.cn (W.Z.); fusheng_tsai@hotmail.com (F.-S.T.)
}

Received: 9 July 2019; Accepted: 26 August 2019; Published: 2 September 2019

\begin{abstract}
In an era of industrial transformation, manufacturing employees have faced significant threats (e.g., Artificial Intelligence technologies). Against such a backdrop, this study empirically examined the relationship between social responsibility toward the employees (CSRe) and career development sustainability, since non-contractual organizational supports are as important for employees' career development as those outlined within contracts. We examined relevant issues in the Chinese manufacturing industry by using decision tree analysis coupled with grey relation processing. CSRe was conceptualized by four dimensions: working benefit, working environment, working hours, and training, while career development sustainability was captured from the perspectives of career growth and employability. The results indicated that four factors of social responsibility toward employees were positively associated with career growth and employability under career development sustainability. In addition, the strongest correlation was between training and career growth as well as employability. This study contributes by enriching the current research on corporate social responsibility from the standpoint of employees, and also generates implications for career development sustainability. Studying in a context of timely importance, this paper has practical implications for manufacturers to respond to the human resource dilemma under the impact of new technology, and thus could help employees embark on a long-term career path, which is conducive to socially sustainable development.
\end{abstract}

Keywords: social responsibility toward the employees (CSRe); career development sustainability; manufacturing transformation

\section{Introduction}

Research estimates that one-third of job roles could be replaced by robots in the future [1]. For example, it is reported that some courier companies in China such as Shentong Express (STO) and Shunfeng Express (SF) have used robots to pick up and deliver goods [2]. Against such a backdrop, one way to respond to the challenges brought by new manufacturing technologies is to enhance the quality of employees' career sustainability. Although many manufacturing companies benefit from new technology, the employment problem still bothers them because of challenges that cannot be ignored, such as high turnovers, recruitment difficulties, labor shortage, etc. 
Among these problems, a lack of career development continues to be a major cause of employee dissatisfaction and turnover [3]. Hence, employee career programs should be developed in order to strengthen their organizational commitment [3]. Also, empirical evidence suggested that organizations' attention to employees' well-being and career advancement was conducive to making commitment-focused human resources (HR) attributions [4]. Facilitation for employees' continuous career development could retain potentially valuable employees by developing their capabilities to avoid being replaced by technologies $[5,6]$.

Following the veins of the above discussion, the present study proposes an innovative way in research to answer the challenging question of how to facilitate employee career sustainability in the context of new, intelligent technologies in the manufacturing industry. We argue that employees' cognition and capability in strategizing and/or implementing upon corporate social responsibility (CSR), which could hardly be replaced by machine intelligence, is beneficial for their career development sustainability.

Currently, a substantial body of research is concerned with CSR; however, most of them pay attention to CSR's effects on consumers or other external stakeholders. Recently, the CSR literature has shifted the focus to the internal stakeholders such as employees [7,8]. Employees constitute an important part of corporate stakeholders [9]. Hence, social responsibility toward the employees' conduct should be considered essential for the corporation's overall social responsibility performance. A number of studies demonstrated that social responsibility toward the employees could positively affect employees' attitudes and behaviors [8,10]. Nevertheless, there is also a dearth of research exploring manufacturing workers' career development. Therefore, we maintain that employee career sustainability can be explored combined with CSRe initiatives. It is also interesting to investigate their relationship, which is an untapped research area in academics.

There may be differences between employees' perceptions of CSR and its significance to their lives; thus, CSR unfolds a context in which to explore various topics (e.g., career development) [8]. We found that no prior study had addressed the relationship between CSRe and career development sustainability, which was also why we conducted the research. Therefore, the present study will center on this relationship and in doing so address gaps in the literature, including: (1) empirical testing for the issue of social responsibility toward the employees; (2) sustainability concerns related to such issues, and (3) in the context of manufacturing transformation in China. Given the unexplored area for the career sustainability of manufacturing workers, we conceptualized this study from the perspectives of career growth and employability, which was different from the existing career models. Furthermore, this study was conducted among manufacturing employees and helped attract attention to this group. Besides, decision tree based on grey relation, a novel data mining data tool, was adopted to examine the relationship between social responsibility toward the employees and employee career development sustainability. Finally, we also put forward some suggestions to help manufacturing employees promote career development sustainability so as to achieve the mutual benefit of enterprises and employees. To conclude, this paper has great theoretical and practical significance.

The structure of this paper is as follows. In Section 2, we conducted a literature review. In Section 3, hypotheses were developed. In Sections 4 and 5, we reported on the methodology and analytic results. The conclusion was elaborated in Section 6, and finally, theoretical and practical implications were discussed in Section 7.

\section{Literature Review}

\subsection{Social Responsibility toward the Employees}

\subsubsection{Corporate Social Responsibility}

Before investigating social responsibility toward the employees (CSRe), we would like to introduce corporate social responsibility (CSR). The debate over CSR has never declined among policymakers, practitioners, and scholars since it came into existence, which is due to its confusion. Carroll 
characterized CSR as "the social responsibility of business encompasses the economic, legal, ethical, and discretionary expectations that society has of organizations at a given point of time" [11] (p. 500). The most frequently used definition of CSR originated from Davis, who related it to "a firm's response to issues beyond the narrow economic, technical and legal requirements" [12] (p. 313). Consequently, it begins where the law ends. Some people might consider CSR as the moral duty of an organization (e.g., environment protection, employee care), whereas others might perceive it as the practice of improving the relationship with stakeholders. The diversities in relation to culture, economic development, social, legal, and political systems, and expectations result in different CSR polices and understandings among countries. As such, it is necessary to get an overall picture of CSR in the Chinese context.

Although the term CSR dated back to as early as the 1970s in other countries, it was a new term in Chinese academics and business. Chinese culture is deeply rooted in three religions: Confucianism, Buddhism, and Taoism [13]. Thus, within China, CSR thoughts and values are also influenced by these religions. Due to China's economic and political system, CSR had not received much attention until the country's entry into the World Trade Organization (WTO) in 2001 on account of the severe results caused by socially irresponsible behavior (e.g., labor scandals, product safety, and environment degradation) of business in China and the criticism from overseas [14]. Recent years have seen China's economic growth as well as the CSR practices that the government and corporations have made together [15]. The CSR reports are a good embodiment of China's CSR development. Before 2002, no CSR reports had been made public for Chinese listed companies; however, this neglect changed in 2006 when the concept of CSR was included into corporate law. Between 2006 and 2009 the number of China-based CSR reports has increased exponentially [16]. Moon and Shen investigated the scholarly development of CSR in China, and found an increasing prominence of CSR research in China [17]. The findings also revealed that the research focus has dynamically shifted from the ethical dimension to social, environmental, and stakeholder dimensions. Moreover, empirical studies rather than theoretical ones are more inclined to be conducted in the CSR literature. Albeit the research results are generally similar to Lockett et al.'s findings [18], they extend the research scope of CSR in the Chinese setting.

\subsubsection{Social Responsibility toward the Employees}

For an increasing number of studies on CSRe, employees are scarcely regarded as an analysis unit in the CSR literature compared with other stakeholders $[19,20]$. This is astonishing, since talent attraction, employee loyalty, and employee productivity can lead to a company's competitive advantages. Albeit scholars have shown greater interest in the individual-level (or employees) CSR literature [7,21], most articles are concerned with the effects of CSR perceptions on employee outcomes such as employee motivation [22], employee engagement [23,24], and employee turnover intention [25]. Employees create value for enterprises; thus, enterprises must perform social responsibility for employees $[9,26]$. Likewise, this internal stakeholder makes greater contributions than capital to the corporation in the knowledge-based society [27]. However, the findings of Nejati and Ghasemi, who investigated the CSR practices in Iran from the perspective of employees, revealed that CSR to employees was the least practiced out of all the CSR activities [28]. Such a result was contrary to employees' role in a firm, which calls for our concern for this key stakeholder in different contexts. The employees in this paper are specifically referred to as incumbent employees, since they can easily perceive the CSR activities in which their organizations engage.

A majority of researchers conceptualized CSR toward employees based on Carroll's classification of CSR from economic, legal, ethical, and philanthropic dimensions [29,30]. Nevertheless, the four components of CSR are not closely related to employees' major concerns during the industry transformation, and thus not appropriately used to address the relationship between CSRe and career development sustainability. In fact, it has not been adequately captured as to how employees perceive their company's CSR [8]. Farooq et al. concluded that CSR toward employees, in Turker's model, stood for a firm's practice that guarantees employees' well-being and benefits through creating a good working environment, "including career opportunities, organizational justice, and 
family-friendly policies as well as training and development" [31] (p. 917). CSRe was conceptually constructed by six dimensions: "employer's CSR orientation, perceived fair wage, perceived level of fairness or discrimination, work benefits, work environment, and remuneration and availability of information" [32] (p. 2). These conceptualizations had implications for our research on CSRe under new situations. Following this paradigm, we constructed four dimensions of CSR toward employees: working benefit, working environment, working hours, and training, coupled with Gao's framework in China [33]. In the present study, working benefit means that enterprises should provide employees with an externally and internally reasonable salary, and pay attention to all aspects of employee benefits, including social insurance payment. The working environment refers to the need for the corporation to create a comfortable, safe, and hygienic working environment for its employees, create a democratic environment for participation, implement a labor protection system, and pay attention to employees' physical and mental health. Working hours implies that organizations should implement national-standard working hours, moderate overtime work, and reasonable arrangement for staff's rest and vacation in order to provide a good balance of work and life. Training signifies enterprises' responsibility to enhance employees' professional skills and offer career advancement opportunities by developing training programs and establishing a clear promotion channel.

\subsection{Career Development Sustainability}

\subsubsection{Definition}

The traditional organizational career prevailing in academia in the early decades of the $20^{\text {th }}$ century highlighted job stability and permanent employment within a single organization [34,35]. However, the later organizational changes such as organizational restructuring generated the notion of a career unconstrained by organizational boundaries in the career development literature [36]. For example, the term "boundaryless career" was used to describe how a career unfolds beyond the borders of a single organization [36]. Likewise, Hall characterized the "protean career" as a contemporary career path that "consists of all of the person's varied experiences in education, training, work in several organizations, changes in occupational field, etc." [34] (p. 201). Despite their respective focus on physical and psychological success and mobility, the current career scholars posit that the two aspects are independent, which gives an impulse to career decision making. Subsequently, the kaleidoscope career concept was introduced in the mid- $20^{\text {th }}$ century, which underscored the influence of nonwork roles on making career-related decisions as an answer to family structural changes and the popularity of dual-career households [37]. As the product of the times, these career theories show how employee career direction develops and career development is conceptualized.

Amid the fast-changing and unpredictable global economic scenario, career sustainability has been made a pressing and prominent concern for individuals, organizations, and societies [38]. The top priority at this moment is that researchers need to identify upfront what is meant by career sustainability. Career sustainability, which is also referred to as a sustainable career, was defined as "sequences of career experiences reflected through a variety of patterns of continuity over time, thereby crossing several social spaces, characterized by individual agency, herewith providing meaning to the individual" [39] (p. 7). This assumption was deduced from the contemporary career, which stated that long-term, linear careers were seemingly unequal to sustainability in such a volatile environment. Modern individuals enjoy a high frequency of employment change. Nevertheless, recent research indicates that employees still desire to sustain careers within an organization [40]. This new organizational career is a new mixture inheriting aspects of the traditional career while including other aspects of the new organizational career. It can adapt to volatile environments, offering the flexibility of a contemporary career within a single organization and fostering positive employer-employee relationships. Hence, the working definition of employee career development sustainability developed in this paper is partly taken from views of the new organizational career [40] and partly from modern environmentalist perspectives on socio-economic development. For the radical environmentalism, 
social economy should achieve sustainable development, that is, it should not reduce choices left to the future generation [41]. Following this holistic approach, we contend that manufacturing employers should seek cost reduction without disregarding the benefits of employees, even in face of industry transformation. Instead, they play an important role in helping employees with career sustainability within an organization.

\subsubsection{Conceptualizing Career Development Sustainability}

Career research is a fertile field; however, there are few publications on career development sustainability. Researchers differ considerably about how career development sustainability should be conceptualized. A dynamic process model on career sustainability was built by providing key indicators of career sustainability—health, happiness, and productivity—and presenting three key dimensions: person, context, and time [42]. Although this systematic framework takes individual, organizational, social, and other factors into account, there is a lack of empirical work to support its validity. Here, we still apply the new organizational career perspective to conceptualizing career development sustainability. From where the new organizational career stands, careers can be jointly managed by employees and employers [40]. Organizations provide employees with career development opportunities, which are incorporated into career growth [43]. The recent literature suggests that career growth opportunity is a key factor affecting employee-organizational relationships [44]. Career development is a dynamic process, including career exploration and career goal setting before entry into organizations, as well as career growth after entry [45]. Career success is also the hyponym of career development; however, it is generally used to evaluate the status of career development. Jans defined career growth as one's perceptions of the development opportunities within an organization [46], while Bedeian et al. referred to it as the utility of one's current job for her/his career [47]. Based on their points, Weng proposed that employee career growth was comprised by career goal progress, professional ability development, promotion speed, and remuneration growth [48]. As manufacturing employees desire to get opportunities to learn more skills and accumulate experience in case of being laid off in the current volatile context, career growth is particularly important for them at this point. Therefore, we contend that career growth can be incorporated into career development sustainability. In the present study, career growth will be confined to one's career growth within one's current organization, rather than in the life-long work stage.

We argued that career development sustainability could be captured by another aspect: employability, which enabled workers to cope with the fast-changing job market. The industry restructuring sets a higher requirement for manufacturing employees; thus, they are in urgent need of obtaining new knowledge and expertise so as to remain employed within or outside the current organization. It appeared to be beneficial for both employee and employers to motivate workers' employability throughout their career [49]. Employability means "the continuous fulfilling, acquiring, or creating of work through the optimal use of competencies" [50] (p. 453). Attention is paid to the individual's assessment of his/her skills, abilities, and capacities that increase employment opportunities. Further, Ling and Qing maintained that employability could be analyzed from three dimensions: within a job, within the current organization, outside the current organization [51]. That is, employability includes both internal and external facets. We preferred to use this operationalization of employability in this paper. Although higher employability requires the endeavor of both organizations and employees, organizations are still expected to help those whose skills may not be improved or are not in high demand to manage their careers through job-specific training and development [52]. Thus, we incorporated employees' self-perceived employability into the study.

Given a lack of insights into employee career sustainability and employment instability in current economic conditions, we try to explore manufacturing workers' career sustainability from the perspectives of career growth and employability. To the best of our knowledge, the extant literature on CSRe explored its effects on organizational commitment [53,54], job satisfaction [55], etc., while research on career growth and employability focused on their relationships with organizational commitment [56] 
and turnover intention [57]. There is a dearth of empirical research examining the relationship between CSRe and career development sustainability. Based on the conceptualization of CSRe and career development sustainability, we propose the structural model (see Figure 1).

\begin{tabular}{|l|l|}
\hline $\begin{array}{c}\text { Social responsibility towards } \\
\text { employees: }\end{array}$ & \multicolumn{1}{c|}{$\begin{array}{c}\text { Career development } \\
\text { sustainability: }\end{array}$} \\
1) Compensation benefit & Working environment \\
3) Working hours & 2) Employability \\
4) Training &
\end{tabular}

Figure 1. Research model.

\section{Hypotheses}

\subsection{CSRe and Career Growth}

This paper explores CSRe from four aspects: working benefit, working environment, working hours, and training, as well as delineates employee career sustainability from two dimensions: career growth and employability.

The extant literature demonstrates the effects of training programs on corporate governance reform and the firm's policies, including work-life balance practices and positive actions designed to create a workplace environment, are conducive to the career advancement of women in firms, which is crucial for shareholder value creation [58]. There is a widespread belief that employee development is positively related to job performance and, naturally, to organizational outcome. Employee development signifies more than helping employees become continuous learners, irrespective of the requirements of the organization. There is a positive relationship between employee CSR practices and employee job satisfaction [59]. One contributing factor to causing job satisfaction is personal growth. As such, we assume that CSRe will positively influence employee career growth.

Hypotheses 1. There will be a positive relationship between CSRe and career growth.

Hypotheses 1a. Working benefit will be positively associated with career growth.

Hypotheses $\mathbf{1 b}$. Working environment will be positively associated with career growth.

Hypotheses 1c. Working hours will be positively associated with career growth.

Hypotheses 1d. Training will be positively associated with career growth.

\subsection{CSRe and Employability}

Very few CSRe research studies have examined its direct link with employee career development. CSRe can produce significant effects on employee competitiveness [32]. Organizational support for competency development has positive implications for employability [60]. Competency development refers to those activities held by the employer and the employee to maintain or promote the employee's functional, learning and career competencies [61], and can be considered as an important organizational effort to undertake social responsibility toward the employees. In addition, training programs have proved to be effective approaches to enhancing employability [51]. Informal and formal learning 
could contribute to employability [62]. Age, salary, and learning environment appeared to be strong indicators of informal learning, while promotion was shown to be a major contributor to employability. Thus, we expect that CSRe will be positively associated with employee self-perceived employability and propose the following hypotheses.

Hypotheses 2. There will be a positive relationship between CSRe and employability.

Hypotheses 2a. Working benefit will be positively related to employability.

Hypotheses $\mathbf{2 b}$. Working environment will be positively related to employability.

Hypotheses 2c. Working hours will be positively related to employability.

Hypotheses 2d. Training will be positively related to employability.

\section{Research Design}

\subsection{Sample}

The research subject of this paper was manufacturing workers. The industrial transformation, especially manufacturing transformation, has swept across the world. China boasts a huge population and a large labor-intensive manufacturing industry. China is among the largest original equipment manufacturer (OEM) economies for other countries' manufacturing prosperity in the world. In the context of manufacturing transformation, an increasing number of production workers who used to do simple and repetitive jobs are plagued by career development sustainability since their jobs are at a risk of being replaced by automation. Thus, it is both interesting and important to conduct research in such context. One of advantages that China boasts-demographic dividend-is gradually diminishing [63]. There is a stronger tendency in which the low-end manufacturing sector has transferred to Southeast Asian countries such as Indonesia, Vietnam, Philippines, etc. We conducted a random questionnaire survey toward eligible manufacturing workers between May 2018 and August 2018 through Sojump, which is a Chinese professional online questionnaire survey, evaluation, and voting platform that provides some powerful functions such as online design questionnaire, data collection and data statistical analysis. Before giving out the survey, we carried out in-depth interviews with several HR professionals and frontline workers from three electromechanical products manufacturing enterprises in Guangzhou, as well as two operation managers of the company, in order to ensure the properness and clearness of our measurements and hypotheses. Their feedback showed that our research framework was feasible. Moreover, under the assistance of some MBA students in Guangdong University of Foreign Studies and corporate leaders working in 10 manufacturing firms, the questionnaire was distributed to 30 of their colleagues who were willing to provide help during their spare time. These respondents were told the significance and purpose of the survey in advance so as to ensure the accuracy and authenticity of data as much as possible. Finally, a total of 331 interviewees from the oil refinery industry, construction machinery industry, electronic manufacturing industry, and textile industry filled in this questionnaire on the online platform. Their working companies operated in nine provinces, autonomous regions, and municipalities of China, including Guangdong, Hubei, Shanghai, Jiangsu, Sichuan, etc. This software helped us to eliminate 12 invalid questionnaires resulting from the answer repetition or short time taken, and we received 319 questionnaires for complete use. Therefore, the response rate was $96.37 \%$. The sample characteristics are shown in Table 1. 
Table 1. Demographic characteristics.

\begin{tabular}{|c|c|c|c|}
\hline Classification. & Variable & Number & Percentage \\
\hline \multirow{2}{*}{ Gender } & Female & 99 & $31.03 \%$ \\
\hline & Male & 220 & $68.97 \%$ \\
\hline \multirow{5}{*}{ Age } & 20 or younger & 1 & $0.31 \%$ \\
\hline & $21-30$ & 77 & $24.14 \%$ \\
\hline & $31-40$ & 145 & $45.45 \%$ \\
\hline & $41-50$ & 81 & $25.39 \%$ \\
\hline & Older than 50 & 15 & $4.70 \%$ \\
\hline \multirow{5}{*}{ Education } & Below diploma & 50 & $15.67 \%$ \\
\hline & 3 years certificate/diploma & 80 & $25.08 \%$ \\
\hline & Bachelor's degree & 128 & $40.13 \%$ \\
\hline & Master's degree & 59 & $18.50 \%$ \\
\hline & Doctor's degree or above & 2 & $0.63 \%$ \\
\hline \multirow{4}{*}{ Position } & Laborial staff & 145 & $45.45 \%$ \\
\hline & Frontline managers & 74 & $23.20 \%$ \\
\hline & Middle managers & 82 & $25.71 \%$ \\
\hline & Senior managers & 18 & $5.64 \%$ \\
\hline \multirow{5}{*}{ Enterprise nature } & State-owned enterprise & 79 & $24.76 \%$ \\
\hline & Private enterprise & 63 & $19.75 \%$ \\
\hline & Foreign-owned enterprise & 50 & $15.67 \%$ \\
\hline & Joint venture & 98 & $30.72 \%$ \\
\hline & Others & 29 & $9.09 \%$ \\
\hline \multirow{6}{*}{ Job nature } & Research and development & 30 & $9.40 \%$ \\
\hline & Production & 108 & $33.86 \%$ \\
\hline & Business & 49 & $15.36 \%$ \\
\hline & Administration & 55 & $17.24 \%$ \\
\hline & Technician & 46 & $14.42 \%$ \\
\hline & Others & 31 & $9.72 \%$ \\
\hline
\end{tabular}

\subsection{Measures}

The survey comprises measures aimed to capture two concepts being investigated in this paper: CSRe and career development sustainability. At this point, all of the items in this part employed a Likert five-grade scale format, where participants were required to score according to their degree of agreement with the statements. The scores ranged from 1, indicating 'strongly disagree', to 5, indicating 'strongly agree'.

\subsubsection{CSRe}

Despite the wide use of Carroll's measurement consisting of four types of responsibility, we argue that it was not directed toward our research focus. Instead, we chose to use Gao's 16-item scale considering our construct of CSRe in this study [33]. This scale includes remuneration benefit, working environment, time commitments, and training development, and also demonstrated the satisfactory reliability, with the coefficient alpha being 0.855 [33]. The scale items were all designed in Chinese. An example item was, "The organization attaches great importance to employee vocational skills training".

\subsubsection{Career Development Sustainability}

Since career development sustainability in the present study could be captured from two facets - career growth and employability - the measures also include these aspects. The career growth scale was originally developed by Weng in Chinese [45]. It contains four dimensions: career goal progress (or the degree to which one's current job is relevant to and provides opportunities for one to achieve their career goals); professional ability development (or the extent to which one's current job 
allows them to acquire new skills and knowledge); promotion speed (or an employee's perceptions of the likelihood and speed of being promoted); and remuneration growth (or employee perceptions of the possibility, speed, and amount of increases in compensation) [45]. Weng and $\mathrm{Xi}$ showed that the scale had good reliability with the coefficient alphas of four subscales being $0.86,0.85,0.80$, and 0.78 . A sample item included, "my present job moves me closer to my career goals" [64].

The employability scale was originally developed by Rothwell and Arnold, which proved to be reliable with the coefficient alphas of the two subscales being 0.72 and 0.79 [49]. It was translated and used in the Chinese context, and proved to have good reliability with the coefficient alphas of internal and external employability being 0.85 and 0.83 in Chinese employees [65]. Considering our research object, we decided to adopt Zeng's Chinese version on employability [65]. One item read, "I have good prospects in this organization, because my employer values my personal contribution". Based on Weng's scale on career growth and Zeng's scale on employability, we established a 14-item measure on employee career development sustainability $[45,65]$.

\section{Results}

\subsection{Descriptive Statistical Analysis}

We made a descriptive statistical analysis of CSRe and employee career development sustainability based on the mean value and standard deviation. The latter reflects the degree of data dispersion. The analysis results (see Table 2) showed that the mean value of all the indicators was between three and four, demonstrating that most of the participants did not disagree with the measurement descriptions. It is noteworthy that career growth had the lowest mean value while working environment had the highest one, which could be explained by the former being so intangible and invisible that employees had difficulty in perceiving it, while the latter could be easily perceived by staff. The standard deviation of all the indicators was approximately 1 , which indicated that the measured values were close to the mean value.

Table 2. Descriptive statistical analysis of variables.

\begin{tabular}{ccccc}
\hline \multicolumn{2}{c}{ Variable Type } & Variable Code & Mean Value & Standard Deviation \\
\hline & Working benefit & X1 & 3.54 & 1.029 \\
Social responsibility & Working environment & X2 & 3.72 & 0.951 \\
toward employees & Working hours & X3 & 3.55 & 0.984 \\
& Training & X4 & 3.58 & 0.979 \\
\hline Career development & Career growth & Y1 & 3.26 & 0.850 \\
sustainability & Employability & Y2 & 3.44 & 0.981 \\
\hline
\end{tabular}

\subsection{Validity and Reliability Analysis}

We examined the internal consistency of two scales in the questionnaire using SPSS 22.0 software. The results showed that Cronbach's $\alpha$ coefficient of the scale of CSRe was 0.942. Put simply, the value of the $\alpha$ coefficient of working benefit, working environment, working hours, and training reached $0.881,0.708,0.814$, and 0.939 . The internal consistency of the scale of employee career development sustainability was supported by the Cronbach's $\alpha$ coefficient of 0.942 . The dimensions of career growth and employability were testified with Cronbach's $\alpha$ coefficients of 0.933 and 0.901 , respectively. The value of the Cronbach's $\alpha$ coefficient in terms of career development sustainability was 0.949 . All these testing results revealed that the used scales in this research had good consistency and reliability.

The construct validity of the scale was tested by factor analysis. The KMO values of two scales were greater than 0.900. Moreover, the values of Bartlett's Test of Sphericity were both $0.000(<0.05)$, which illustrated that these two scales were suitable for factor analysis. The cumulative variance explained of the extracted communities was greater than $60 \%$, which could explain the measured variables. Consequently, all the scales used in this study have good construct validity (Table 3). 
Table 3. Validity and reliability analysis results.

\begin{tabular}{cccccccc}
\hline Scale & Variable & $\begin{array}{c}\text { Item } \\
\text { Number }\end{array}$ & KMO & $\begin{array}{c}\text { Bartlett } \mathbf{X}^{2} \\
\text { Sig. }\end{array}$ & $\begin{array}{c}\text { Cumulative } \\
\text { Variance } \\
\text { Explained (\%) }\end{array}$ & Cronbach's $\alpha$ \\
\hline & $\begin{array}{c}\text { Working } \\
\text { benefit }\end{array}$ & 6 & & & 63.876 & 0.881 \\
$\begin{array}{c}\text { Working } \\
\text { Social responsibility } \\
\text { toward employees } \\
\text { Workingnt } \\
\text { hours } \\
\text { Training }\end{array}$ & 2 & 4 & 0.931 & 0.000 & 77.389 & 0.708 & 0.942 \\
& 4 & & & 72.937 & 0.814 & \\
\hline $\begin{array}{c}\text { Career development } \\
\text { sustainability }\end{array}$ & $\begin{array}{c}\text { Career growth } \\
\text { Employability }\end{array}$ & 8 & 0.933 & 0.000 & 80.955 & 0.933 & 0.949 \\
\hline
\end{tabular}

\subsection{Correlation Analysis}

This paper used SPSS 22.0 software to calculate the correlation analysis of all the variables. The analysis results were as follows (refer to Table 4 ). The results indicated that career growth was positively associated with the four dimensions of CSRe, with the correlation coefficient of training being the highest $(\mathrm{r}=0.693, p<0.01)$, followed by the working benefit $(\mathrm{r}=0.649, p<0.01)$, working environment $(\mathrm{r}=0.576, p<0.01)$, and working hours $(\mathrm{r}=0.494, p<0.01)$. Similarly, employability was positively related to the four aspects of CSRe, with the strongest correlation being training $(\mathrm{r}=0.585, p<0.01)$ and the weakest one being working hours $(r=0.405, p<0.01)$. The significant correlations between the examined variables suggested the validity of the hypotheses.

Table 4. Results of correlation analysis.

\begin{tabular}{|c|c|c|c|c|c|c|c|c|c|c|c|c|}
\hline Variable & 1 & 2 & 3 & 4 & 5 & 6 & 7 & 8 & 9 & 10 & 11 & 12 \\
\hline $\begin{array}{l}1 \text { Working } \\
\text { benefit }\end{array}$ & 1 & $0.774^{* *}$ & $0.675^{* *}$ & $0.757^{* *}$ & $0.649^{* *}$ & $0.556^{* *}$ & -0.048 & $-0.172^{* *}$ & $0.133 *$ & 0.014 & -0.075 & -0.052 \\
\hline $\begin{array}{l}2 \text { Working } \\
\text { environment }\end{array}$ & & 1 & 0.623 ** & 0.722 ** & $0.576^{* *}$ & $0.487^{* *}$ & 0.005 & $-0.185^{* *}$ & $0.181^{* *}$ & 0.057 & -0.125 * & 0.019 \\
\hline $\begin{array}{l}3 \text { Working } \\
\text { hours }\end{array}$ & & & 1 & $0.626^{* *}$ & $0.494^{* *}$ & $0.405^{* *}$ & -0.024 & -0.125 * & 0.121 * & 0.017 & -0.060 & -0.036 \\
\hline 4 Training & & & & 1 & $0.693^{* *}$ & $0.585^{* *}$ & -0.049 & -0.128 * & $0.167^{* *}$ & 0.043 & -0.065 & -0.066 \\
\hline $\begin{array}{l}5 \text { Career } \\
\text { growth }\end{array}$ & & & & & 1 & 0.781 ** & $-0.117^{*}$ & $-0.244^{* *}$ & $0.175^{* *}$ & 0.035 & -0.085 & -0.077 \\
\hline $\begin{array}{l}6 \\
\text { Employability }\end{array}$ & & & & & & 1 & $-0.111^{*}$ & $-0.234^{* *}$ & 0.107 & -0.009 & -0.071 & -0.072 \\
\hline 7 Gender & & & & & & & 1 & 0.048 & $0.211 * *$ & 0.019 & $-0.194 * *$ & $0.263^{* *}$ \\
\hline 8 Age & & & & & & & & 1 & $-0.185^{* *}$ & 0.233 ** & 0.039 & 0.034 \\
\hline $\begin{array}{l}9 \text { Education } \\
\text { background }\end{array}$ & & & & & & & & & 1 & $0.389^{* *}$ & $-0.224^{* *}$ & $0.258^{* *}$ \\
\hline $\begin{array}{l}10 \text { Position } \\
11\end{array}$ & & & & & & & & & & 1 & $-0.237^{* *}$ & 0.109 * \\
\hline $\begin{array}{l}\text { Enterprise } \\
\text { nature }\end{array}$ & & & & & & & & & & & 1 & -0.034 \\
\hline 12 Job nature & & & & & & & & & & & & 1 \\
\hline
\end{tabular}

Note: * indicates $p<0.05,{ }^{* *}$ indicates $p<0.01$.

Moreover, we found that gender was negatively linked with career growth $(\mathrm{r}=-0.117, p<0.05)$ and employability $(\mathrm{r}=-0.111, p<0.05)$. The relations revealed the career sustainability gap between male and female employees in China, and that women might not receive the same career development care as men did in the organization. Obviously, age was negatively related to working benefit $(\mathrm{r}=$ $-0.172, p<0.01)$, working environment $(\mathrm{r}=-0.185, p<0.01)$, and working hours $(\mathrm{r}=-0.125, p<0.05)$. Age was also negatively associated with training $(\mathrm{r}=-0.128, p<0.05)$, career growth $(\mathrm{r}=-0.244, p$ $<0.01)$, and employability $(\mathrm{r}=-0.234, p<0.01)$. Education background was positively correlated with the above dimensions except for employability. It could be explained by the fact that most of the older employees might not receive higher education and work in the frontline, which led to their perceived lower CSRe and career development sustainability. Besides, enterprise nature was negatively associated with working environment $(\mathrm{r}=-0.125, p<0.05)$. 


\subsection{Decision Tree Analysis}

Decision tree is a non-parametric supervised learning method used for classification and regression that aims to create a model that predicts a dependent variable by including several independent variables in it [66]. There are various types of decision trees. According to the differences in the core algorithms of their splits, there are mainly Gini, C4.5, CHAIN, C5.0, ID3, CART, etc. Different splitting methods generate different decision trees. Salehzadeh endeavored to find the appropriate leadership styles based on the followers' preferences using the decision tree technique [67].

Through correlation analysis, the relationship between CSRe and career development sustainability has been confirmed. Decision tree analysis via the C5.0 algorithm helps to detect the relations between independent and dependent variables and find the differences so as to identify what affects employee career development sustainability most.

In this paper, we established two decision trees for four independent variables (X1, $\mathrm{X} 2, \mathrm{X} 3$, and $\mathrm{X} 4)$ and two dependent variables (Y1 and $\mathrm{Y} 2$ ) based on $\mathrm{C} 5.0$ to further investigate under what conditions an independent variable affects $\mathrm{Y} 1$ and $\mathrm{Y} 2$. Before the decision tree analysis, we adopted MATLAB software to do grey relation processing, since there were various items in terms of each dimension, and their relations with dimension were varying. On the basis of the standard values of each item, reference values for independent variables such as $\mathrm{X} 1, \mathrm{X} 2, \mathrm{X} 3$, and $\mathrm{X} 4$ as well as dependent variables such as $\mathrm{Y} 1$ and $\mathrm{Y} 2$ would be derived by means of grey relation. In doing so, we could make a further analysis in an easier manner.

As the value type of dependent variables was featured by numeric data, it should be converted into the category type composed by high, middle, and low so as to visually present results. In the present study, the top $30 \%$ values were classified as low class, the middle $40 \%$ of values were classified as middle class, and the remaining 30\% values were classified as high class based on normal distribution. Finally, we obtained two decision trees (see Figures 2 and 3) using R language software.

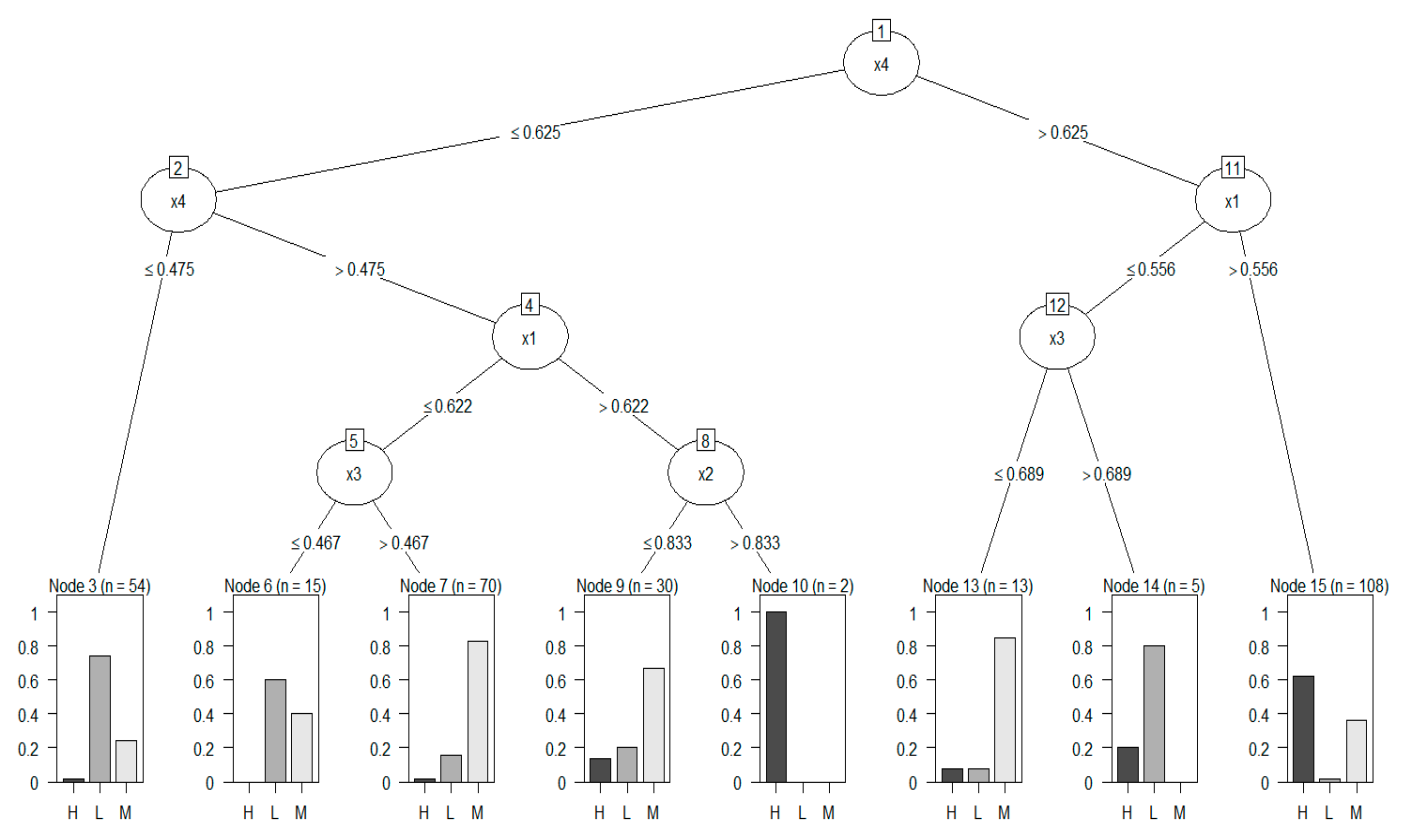

Figure 2. Decision tree of $\mathrm{X} 1-\mathrm{X} 4$ and $\mathrm{Y} 1$. 


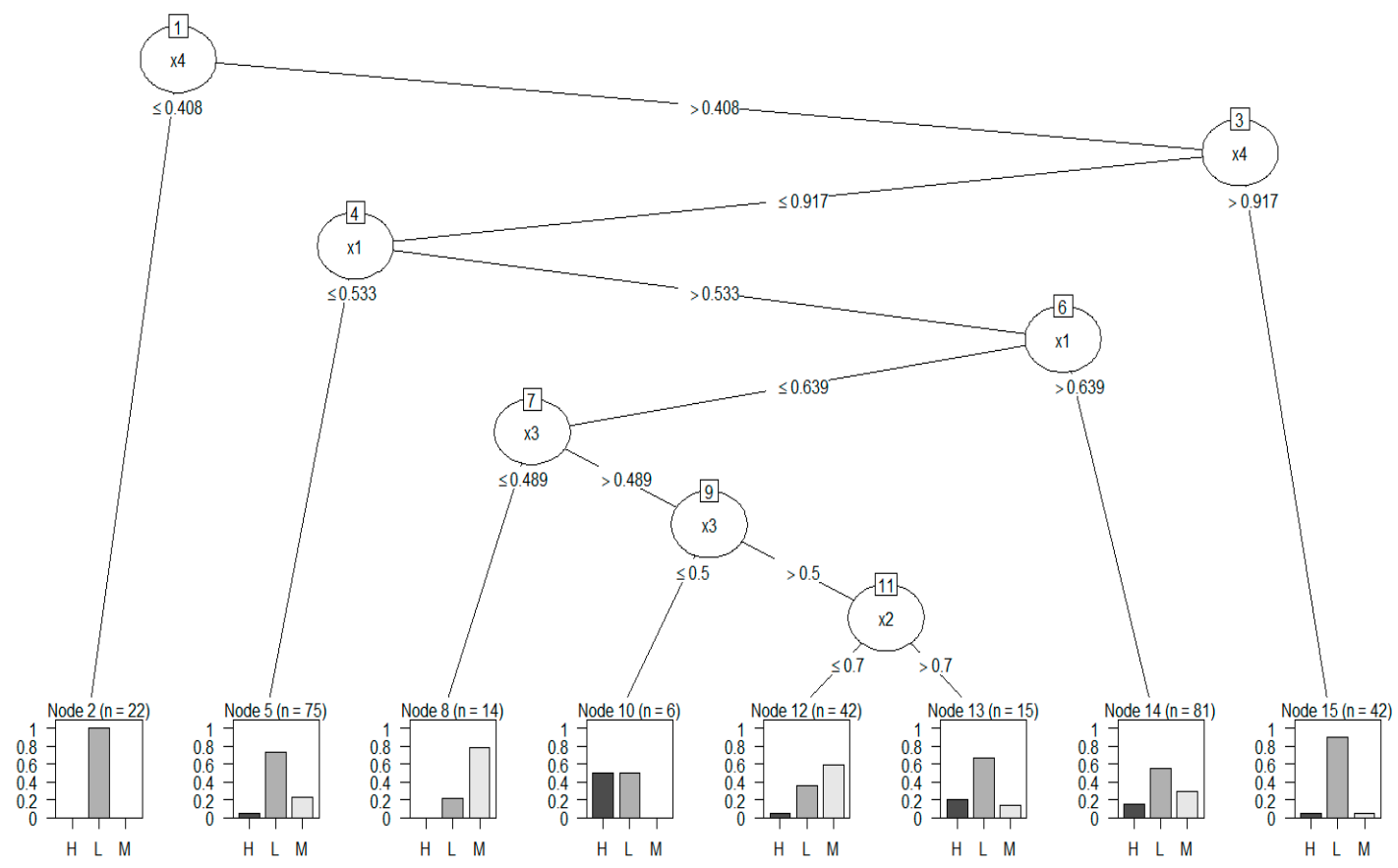

Figure 3. Decision tree of $\mathrm{X} 1-\mathrm{X} 4$ and $\mathrm{Y} 2$.

These independent variables, which were mutually influenced, were equivalent to the choices facing the tree. In this context, the high, middle, and low class of $Y 1$ stood for its significant level. The tree showed that it consisted of two branches, each of which gave rise to different results. X4 stood at the top of the tree, and was the key determinant of $Y 1$. On the basis of $X 4$, other factors would generate outcomes. Obviously, if and only if $X 4$ was $>0.625$ and $X 1$ was $>0.556$, there would be the largest number of $\mathrm{Y} 1$ distributing in the high and middle value areas. In other words, $\mathrm{X} 4$ and $\mathrm{X} 1$ are the most significant predicators of $Y 1$. When the conditions were satisfied $(0.475<\mathrm{X} 1<\mathrm{X} 4 \leq 0.625$ and $\mathrm{X} 1 \leq 0.622 \leq \mathrm{X} 3$ ), $\mathrm{Y} 1$ would have the second largest quantity of the middle and high value. The conditions of $0.475<\mathrm{X} 1<\mathrm{X} 4 \leq 0.625$ and $0.622<\mathrm{X} 2<\mathrm{X} 1$ would also bring good results, which lagged behind the above two conditions. It meant that career growth was strongly affected by $X 4$, followed by $\mathrm{X} 1, \mathrm{X} 3$, and $\mathrm{X} 2$. Thus, we concluded that training, working benefit, working hours, and working environment was positively associated with career growth under career development sustainability, which tested Hypothesis 1.

Figure 3 showed that all the conditions were determined by $X 4$, underlying its strongest impact on $Y 2$. However, if $X 4$ was $\leq 0.408, Y 2$ would go to the low-value area, which meant that $X 4$ could not be solely considered if amazing effects were desired most. Then, we had to go deeper only when X4 was $>0.408$. In a same veil, the condition of $X 4>0.917$ did not work well. Thus, if and only if $X 4$ was $\leq 0.917$ and $\mathrm{X} 1$ was $\leq 0.533$, Y2 would present high and middle values, which were much less than the low value. When the conditions were met $(0.639<\mathrm{X} 1<\mathrm{X} 4 \leq 0.917)$, the largest number of high and middle values of $Y 2$ would appear. In this sense, $X 4$ and $X 1$ could bring the greatest influences on $Y 2$. Similarly, such conditions as X $2 \geq 0.7$ and $0.5<\mathrm{X} 3<\mathrm{X} 1<0.639<\mathrm{X} 4 \leq 0.917$ could also lead to good results, with the middle and high areas taking a larger part. In other words, the degree of impacts on employability brought by independent variables ranged from training to working benefit, working hours, and working environment. Therefore, the four dimensions of CSRe were positively associated with employability under career development sustainability, which tested Hypothesis 2.

\section{Discussion}

This study focused on the role of social responsibility toward the employees to promote an understanding of career sustainability of Chinese manufacturing employees. First, the research 
results provided a strong support for social responsibility toward the employees' effects on career development sustainability. In detail, CSRe was positively correlated with career development sustainability. The working benefit, working environment, working hours, and training under CSRe could produce positive effects on career growth and employability under employee career development sustainability. In this sense, if organizations undertake social responsibility toward the employees well, it is reasonable that employee career growth and employability will be promoted, thus benefiting career development sustainability.

Second, the analysis results also indicated that training and working benefit made the greatest contributions to career growth and employability. Training is both significant and valuable for the employee and the employer. Thanks to new knowledge and skills acquisition, an employee can shoulder his/her professional duties better or even complete more creative and complicated tasks. Hence, training pushes forward the subsequent professional development and/or career growth for the employee [68]. In the face of market changes, adequate training to employees contributes to corporate growth and prosperity [69]. If employees are provided with good working benefit, their basic living conditions can be guaranteed so that they will have better career aspirations. Previous research results reveal that compensation and benefit policies significantly influence the ability of firms to recruit and retain core employees, which is necessary for corporate success [70].

Third, a significant finding in this study is that employee career development sustainability can be captured from career growth and employability, which have never been integrated before. In the context of frequent employment changes, understanding the career sustainability of Chinese manufacturing employees is of paramount importance for both Chinese and global organizations so that the work relationships with this population can be improved.

\section{Conclusions}

Theoretically, the paper contributes to the literature significantly. On the one hand, this paper enriches the literature regarding CSR to employees by empirically testing CSRe's influences on its nomological outcome. Furthermore, we claimed that the results of this study could shed light on the conceptual development and practical implementation for employee career development, by adding the "sustainability" dimension to this construct.

Practically, the findings have implications for both individuals and organizations. For organizations, it is of remarkable significance to incorporate employee career management into the agenda and provide it with the supporting system. The new technology is likely to challenge some labor jobs, whereas it will also bring some new opportunities in the manufacturing industry. Thus, employers can implement flexible training programs to broaden the knowledge, skills, and abilities of employees, thus allowing them fit in job rotations in various departments. Since employees' knowledge and skills must keep pace with times so that more innovation can be generated in the new era, off-the-job and on-the-job training programs consisting of skill and career management training can also stimulate staff potential and creativity. As regards employee career management training, enterprises can offer guidance on staff's career development. For instance, it is advisable to provide sufficient career management information and occasionally deliver career-planning lectures for employees. Besides, a fair promotion channel should be established in that a clear career development pathway not only makes for employee self-development, but also motivates employees to increase their work input. For workers who are unable to accomplish job rotation or keep their job, organizations must compensate for the dismissal, helping them to understand their career orientation. In doing so, employers not only fulfill the responsibility for employees, they also acquaint themselves with their own deficiencies.

To promote employee career sustainability, organizations must design a reasonable and flexible benefit system linked with a good performance assessment system for employees as well. Salary and welfare have been the primary concerns of employees to seek and retain a job. The two items, to a large extent, represent the recognition of employees' job devotion. It is widely accepted that an excellent 
remuneration system can promote employees' job satisfaction and organizational commitment. As a matter of fact, this financial factor runs through the whole career development process, and can mirror the track of career growth. Hence, the provision of salary and welfare should be also valued. Finally, the manufacturing businesses should never ignore the importance of the working environment and working hours, which still influence employee career development.

As for manufacturing workers, they should also acquire new knowledge and skills when they are off the job, apart from receiving training and development programs offered by employers, which contribute to improving their employability. Of course, it is indispensable for them to establish career plans and define career goals as soon as possible, which benefit their career growth, so as not to be eliminated in the fast-changing working environment.

As our sample is composed of employees in Chinese manufacturing enterprises, the research findings may not be generalized to other industries or other regions. Thus, further studies could extend the scope to check the possible differences. Also, we argue that employee career development sustainability can be captured from career growth and employability; nevertheless, there is no guarantee that these two dimensions are all-inclusive measures of this notion. Future research should emphasize the further interpretation of this concept and its measurement, and address the possible intersection between these dimensions, which will deepen our understanding of how factors related to each of the two dimensions might produce interactive influences on career sustainability. With scarce research on the relationship between social responsibility toward employees and career development sustainability, it calls for further exploration of how CSRe interacts with other determinants of career development sustainability and the role of individual differences in shaping career development sustainability. Additionally, in the special context of the new manufacturing era, the interaction between CSR-invested employees and technology could be investigated. Will these measures decrease the rate of employee replacement with technological means? What types of benefits could bring in committed employees instead of new technologies? These are examples of research questions that could be examined. Furthermore, the result of the studied issue might also be affected by company policy or individual personality (e.g., the company has no CSR policy at all, or on the contrary, the company's CSR awareness is extremely high). Besides, the relationship between social responsibility toward the employees and their career development sustainability might be affected by culture, since culture is a separate context where employee intentions and behaviors are embedded. In such sense, the effects and/or consequences that employees intentions and behaviors could have on the organization are contingent across different cultures. Finally, since career development sustainability is an ongoing process, more solid longitudinal research is needed to study how career sustainability has changed over time and how factors relate to each other.

Author Contributions: Data curation, X.L.; Methodology, X.L.; Formal Analysis: X.L.; Writing-Original draft: W.Z.; Writing-review and editing: F.-S.T.

Funding: This research is part of a larger study of 2019 Program, “On Behavioral Motivation and Influencing Mechanism of Overseas Social Responsibility of Chinese Enterprises" by The National Social Science Fund of China (Grant number: 19BGL116).

Acknowledgments: The authors wish to thank Wang and Guo who helped collect part of the data, and the authors also express gratitude to Pan and $\mathrm{Xu}$ for providing suggestions to this paper.

Conflicts of Interest: The authors declare no conflict of interest.

\section{References}

1. China Daily. 700 Smart Machines Sorting out 200,000 Packages in a Day. Available online: http://tech. chinadaily.com.cn/2017-05/05/content_29222038.htm (accessed on 5 May 2015). (In Chinese).

2. Frey, C.B.; Osborne, M.A. The future of employment: How susceptible are jobs to computerization? Technol. Forecast. Soc. Change 2013, 114, 254-280. [CrossRef]

3. Davis, P.J. Implementing an employee career-development strategy. Hum. Res. Manag. Int. Dig. 2015, 23, 28-32. [CrossRef] 
4. Fontinha, R.; Chambel, M.J.; Cuyper, N.D. HR attributions and the dual commitment of outsourced it workers. Pers. Rev. 2012, 41, 832-848. [CrossRef]

5. Malik, A.R.; Singh, P.; Chan, C. High potential programs and employee outcomes: The roles of organizational trust and employee attributions. Career Dev. Int. 2016, 22, 772-796. [CrossRef]

6. McDonnell, A.; Collings, D.; Mellahi, K.; Schuler, R. Talent management: A systematic review and future prospects. Eur. J. Int. Manag. 2017, 11, 86-128. [CrossRef]

7. Aguinis, H.; Glavas, A. What we know and don't know about corporate social responsibility: A review and research agenda. J. Manag. 2012, 38, 932-968. [CrossRef]

8. Glavas, A. Corporate social responsibility and organizational psychology: An integrative review. Front. Psychol. 2016, 7, 144. [CrossRef] [PubMed]

9. Freeman, R.E. Strategic Managment: A Stakeholder Approach; Pitman Press: Boston, MA, USA, 1984.

10. De Roeck, K.; Maon, F. Building the theoretical puzzle of employees' reactions to corporate social responsibility: An integrative conceptual framework and research agenda. J. Bus. Ethics 2016, 149, 609-625. [CrossRef]

11. Carroll, A.B. A three-dimensional conceptual model of corporate performance. Acad. Manag. Rev. 1979, 4, 497-505. [CrossRef]

12. Davis, K. The case for and against business assumption of social responsibilities. Acad. Manag. J. 1973, 16, 312-322. [CrossRef]

13. Lou, Y. Confucianism, Buddhism and Taoism in Chinese culture. Forum Chin. Cult. 1994, 3, 38-47. (In Chinese)

14. Gao, Y. CSR in an emerging country: A content analysis of CSR reports of listed companies. Balt. J. Manag. 2011, 6, 263-291. [CrossRef]

15. Yin, J.; Zhang, Y. Institutional dynamics and corporate social responsibility (CSR) in an emerging country context: Evidence from China. J. Bus. Ethics 2012, 111, 301-316. [CrossRef]

16. Marquis, C.; Qian, C.L. Corporate Social Responsibility Reporting in China: Symbol or Substance? Org. Sci. 2014, 25, 127-148. [CrossRef]

17. Moon, J.; Shen, X. CSR in China research: Salience, focus and nature. J. Bus. Ethics 2010, 94, 613-629. [CrossRef]

18. Lockett, A.; Moon, J.; Visser, W. Corporate Social Responsibility in Management Research: Focus, Nature, Salience and Source of Influence. J. Manag. Stud. 2006, 43, 115-136. [CrossRef]

19. Aguilera, R.V.; Rupp, D.E.; Williams, C.A.; Ganapathi, J. Putting the S back in corporate social responsibility: A multi-level theory of social change in organizations. Acad. Manag. Rev. 2007, 32, 836-863. [CrossRef]

20. Rodrigo, P.; Arenas, D. Do Employees Care about CSR Programs? A Typology of Employees According to Their Attitudes. J. Bus. Ethics 2008, 83, 265-283. [CrossRef]

21. Morgeson, F.P.; Aguinis, H.; Waldman, D.A.; Siegel, D.S. Extending corporate social responsibility research to the human resource management and organizational behavior domains: A look to the future. Pers. Psychol. 2013, 66, 805-824. [CrossRef]

22. Skudiene, V.; Auruskeviciene, V. The contribution of corporate social responsibility to internal employee motivation. Balt. J. Manag. 2012, 7, 49-67. [CrossRef]

23. Opoku-Dakwa, A.; Chen, C.C.; Rupp, D.E. CSR initiative characteristics and employee engagement: An impact-based perspective. J. Org. Behav. 2018, 39, 580-593. [CrossRef]

24. Glavas, A. Corporate social responsibility and employee engagement: Enabling employees to employ more of their whole selves at work. Front. Psychol. 2016, 7, 1-10. [CrossRef] [PubMed]

25. Lin, C.; Liu, M. Examining the effects of corporate social responsibility and ethical leadership on turnover intention. Pers. Rev. 2017, 46, 526-550. [CrossRef]

26. Clarkson, M.E. A Stakeholder framework for analyzing and evaluating corporate social performance. Acad. Manag. Rev. 1995, 20, 92-117. [CrossRef]

27. Handy, C. The Elephant and the Flea: Looking Backward to the Future; Hutchinson: London, UK, 2001.

28. Nejati, M.; Ghasemi, S. Corporate social responsibility in Iran from the perspective of employees. Soc. Responsib. J. 2012, 8, 578-588. [CrossRef]

29. Cao, G.; Liu, W.S.; Liao, Y.D.; Jiang, S.L. Relationships among Corporate Social Performance, Employees Satisfaction and Turnover: A Case Study of Auto Stores in Guangdong Province of China. J. South China Univ. Tech. 2014, 4, 9-15. (In Chinese) 
30. He, K. A study of the influence of the enterprise staff's responsibilities on the organizational citizenship behavior of new generation staff. J. Manag. 2018, 31, 33-43. (In Chinese)

31. Farooq, M.; Farooq, O.; Jasimuddin, S.M. Employees response to corporate social responsibility: Exploring the role of employees' collectivist orientation. Eur. Manag. J. 2014, 32, 916-927. [CrossRef]

32. Cheruiyot, T.K.; Tarus, D.K. Modeling employee social responsibility as an antecedent to competitiveness outcomes. SAGE Open 2015, 5, 1-8. [CrossRef]

33. Gao, Z.L. Research on the Influence of Corporate Employee Social Responsibility on Turnover Intention. Master's Thesis, Southwest University, Chongqing, China, 25 May 2017. (In Chinese).

34. Hall, D.T. Careers in Organizations; Goodyear Publishing: Santa Monica, CA, USA, 1976.

35. Weber, M. The Theory of Social and Economic Organization; Oxford University Press: New York, NY, USA, 1947.

36. Arthur, M.B.; Rousseau, D.M. The Boundaryless Career: A New Employment Principle for A New Organizational Era; Oxford University Press: New York, NY, USA, 1996.

37. Mainiero, L.A.; Sullivan, S.E. Kaleidoscope careers: An alternate explanation for the "optout" revolution. Acad. Manag. Exec. 2005, 19, 106-123. [CrossRef]

38. Lawrence, B.S.; Hall, D.T.; Arthur, M.B. Sustainable careers then and now. In Handbook of Research on Sustainable Careers; De Vos, A., Van der Heijden, B.I.J.M., Eds.; Edward Elgar: Cheltenham, UK, 2015.

39. Van der Heijden, B.I.J.M. No One Has ever Promised you a Rose Garden. On Shared Responsibility and Employability Enhancing Strategies Throughout Careers; Van Gorcum: Assen, The Netherlands, 2005.

40. Clarke, M. The organizational career: Not dead but in need of redefinition. Int. J. Hum. Res. Manag. 2013, 24, 684-703. [CrossRef]

41. Pepper, D. Modern Environmentalism: An Introduction; Routledge: London, UK, 1996.

42. De Vos, A.; Van der Heijden, B.I.J.M.; Jos, A. Sustainable careers: Towards a conceptual model. J. Vocat. Behav. 2018, 1-13. [CrossRef]

43. Litano, M.L.; Myers, D.P.; Major, D.A. How can men and women be allies in achieving work-family balance? The role of coping in facilitating positive crossover. In Gender in Organizations: Are Men Allies or Adversaries to Women's Career Advancement? Major, D.A., Ronald, J.B., Eds.; Edward Elgar: Cheltenham, UK, 2014; pp. 365-384.

44. Weng, Q.X.; McElroy, J.C. Organizational career growth, affective occupational commitment and turnover intentions. J. Vocat. Behav. 2012, 80, 256-265. [CrossRef]

45. Weng, Q.X. The Impact Mechanism of Career Growth on Employees' Commitment and Turnover. Ph.D. Thesis, Huazhong University of Science and Technology, Wuhan, China, 28 April 2009. (In Chinese).

46. Jans, N.A. Organizational commitment, career factors and career/life stage. J. Org. Behav. 1989, 10, $247-266$. [CrossRef]

47. Bedeian, A.G.; Kemery, E.R.; Pizzolatto, A.B. Career commitment and expected utility of present job as predictors of turnover intentions and turnover behavior. J. Vocat. Behav. 1991, 39, 331-343. [CrossRef]

48. Weng, Q.X. Career Growth Study: Scale development and validity test. Manag. Rev. 2010, $22,22-31$. (In Chinese)

49. Rothwell, A.; Arnold, J. Self-perceived Employability: Development and Validation of a Scale. Pers. Rev. 2007, 36, 23-41. [CrossRef]

50. Van der Heijde, C.M.; Van der Heijden, B.I.J.M. A competence-based and multidimensional operationalization and measurement of employability. Hum. Res. Manag. 2006, 45, 449-476. [CrossRef]

51. Ling, L.; Qing, T. Can training promote employees' organizational commitment? The effect of employability and expectation value. Nankai Bus. Rev. Int. 2013, 16, 127-139. (In Chinese)

52. Clarke, M.; Margaret, P. The new covenant of employability. Empl. Relat. 2008, 30, 121-141. [CrossRef]

53. Mory, L.; Wirtz, B.W.; Vincent, G. Factors of internal corporate social responsibility and the effect on organizational commitment. Int. J. Hum. Res. Manag. 2016, 27, 1393-1425. [CrossRef]

54. Turker, D. How corporate social responsibility influences organizational commitment. J. Bus. Ethics 2009, 89, 189-204. [CrossRef]

55. Tziner Aharon, O.L.; Bar, Y.; Kadosh, G. Corporate social responsibility, organizational justice and job satisfaction; how do they interrelate, if at all? J. Work Org. Psychol. 2011, 27, 67-72. [CrossRef]

56. Weng, Q.X.; McElroy, J.C.; Morrow, P.C.; Liu, R.Z. The relationship between career growth and organizational commitment. J. Vocat. Behav. 2010, 77,391-400. [CrossRef] 
57. Chen, J.Q.; Hou, Z.J.; Li, X.; Lovelace, K.J.; Liu, Y.L.; Wang, Z.L. The role of career growth in Chinese new employee's turnover process. J. Career Dev. 2016, 43, 11-25. [CrossRef]

58. Takanori, T. Foreign investors and corporate social responsibility: Evidence from the career advancement of women in Japan. Appl. Econ. 2015, 47, 3510-3524. [CrossRef]

59. Cheruiyot, T.K.; Maru, L.C. Employee social responsibility practices and outcomes in Kenya's tourist hotels. Afr. J. Econ. Manage. Studies 2012, 3, 23-41. [CrossRef]

60. De Vos, A.; De Hauw, S.; Van der Heijden, B.I.J.M. Competency development and career success: The mediating role of employability. J. Vocat. Behav. 2011, 79, 438-447. [CrossRef]

61. Forrier, A.; Sels, L. The concept employability: A complex mosaic. Int. J. Hum. Res. Dev. Manag. 2003, 3, 102-124. [CrossRef]

62. Van der Klink, M.; Van der Heijden, B.I.J.M.; Boon, J.; Van Rooij, S.W. Exploring the contribution of formal and informal learning to academic staff member employability: A Dutch perspective. Career Dev. Int. 2014, 19, 337-356. [CrossRef]

63. Cai, F.; Zhao, W. When Demographic Dividend Disappears: Growth Sustainability of China. Chin. Econ. J. 2012, 75-90. [CrossRef]

64. Weng, Q.; Xi, Y. The impact mechanism of career growth on turnover intention: The mediated role of career commitment and perceived opportunities. Nankai Bus. Rev. 2010, 13, 119-131. (In Chinese)

65. Zeng, C. Validation of Chinese Version of Self-perceived Employability Scale. Chin. J. Clin. Psychol. 2011, 19, 41-44. (In Chinese)

66. Cervone, H.F. Applied digital library project management: Using decision tree analysis to clarify multipath problems. OCLC Syst. Serv. 2010, 26, 14-17. [CrossRef]

67. Salehzadeh, R. Which types of leadership styles do followers prefer? A decision tree approach. Int. J. Edu. Manag. 2017, 31, 865-877. [CrossRef]

68. Kucherov, D.; Manokhina, D. Evaluation of training programs in Russian manufacturing companies. Eur. J. Train. Dev. 2017, 41, 119-143. [CrossRef]

69. Cheung, H.Y.; Chan, A.W. Increasing the competitive positions of countries through employee training: The competitiveness motive across 33 countries. Int. J. Manpow. 2012, 33, 144-158. [CrossRef]

70. Vidal-Salazar, M.D.; Cordón-Pozo, E.; de la Torre-Ruiz, J.M. Flexibility of benefit systems and firms' attraction and retention capacities. Empl. Relat. 2016, 38, 487-504. [CrossRef]

(C) 2019 by the authors. Licensee MDPI, Basel, Switzerland. This article is an open access article distributed under the terms and conditions of the Creative Commons Attribution (CC BY) license (http://creativecommons.org/licenses/by/4.0/). 